\title{
PENGARUH KUALITAS PELAYANAN PRAMUWISATA LOKAL TERHADAP KEPUASAN DAN LOYALITAS WISATAWAN DI DAYA TARIK WISATA ALAS KEDATON TABANAN
}

\author{
I Kadek Trita Yudi \\ Ni Made Oka Karini \\ Luh Gede Leli Kusuma Dewi \\ Email : tritayudi@gmail.com \\ PS. S1 Industri Perjalanan Wisata \\ Fakultas Pariwisata UNUD
}

\begin{abstract}
ABSTRAK
Pelayanan prauwisata lokal di daya tarik wisata Alas Kedaton secara tidak langsung berpengaruh terhadap kepuasan dan loyalitas wisatawan. Oleh sebab itu perlu dikaji mengenai pengaruh kualitas pelayanan pramuwisata lokal terhadap kepuasan dan loyalitas wisatawan di daya tarik wisata Alas Kedaton. Adapun variabel kualitas pelayanan yang terdiri dari bukti langsung, empati, daya tanggap, keandalan dan jaminan berpengaruh terhadap kepuasan dan loyalitas wisatawan di Daya Tarik Wisata Alas Kedaton. Responden adalah wisatawan yang berkunjung ke Alas Kedaton berjumlah 100 responden dengan teknik accidental sampling.Pengumpulan data dalam penulisan ini menggunakan teknik observasi, wawancara terstruktur, kuesioner dan studi kepustakaan kemudian di analisis dengan analisis skala likert, uji validitas dan realibilitas, analisis regresi linier berganda, analisis korelasi, dan analisis determinasi. Berdasarkan analisis data statistik, indikator dalam penelitian ini telah valid dan variabelnya bersifat reliabel. Berdasarkan hasil penelitian, 5 Variabel independen telah memenuhi syarat penerimaan hipotesis, yaitu $\mathrm{t}_{\text {-hitung }}$ dan $\mathrm{F}_{\text {-hitung }}$ lebih besar dari $\mathrm{t}_{\text {-tabel }}$ dan $\mathrm{F}_{\text {-tabel }}$. Ini berarti terdapat pengaruh yang kuat antara kualitas pelayanan pramuwisata lokal terhadap kepuasan dan loyalitas wisatawan pada Daya Tarik Wisata Alas Kedaton. Kualitas pelayanan pramuwisata lokal berpengaruh sebesar $76,3 \%$ terhadap kepuasan wisatawan, dan 70,5\% terhadap loyalitas wisatawan. Sedangkan sisanya dipengaruhi oleh faktor lain yang tidak diteliti lebih lanjut pada penelitian ini. Berdasarkan analisis tersebut, dapat disimpulkan terdapat hubungan yang signifikan antara kualitas pelayanan pramuwisata lokal terhadap kepuasan dan loyalitas wisatawan di daya tarik wisata Alas Kedaton. Di sarankan kepada pengelola, perlu diadakan pelatihan khusus terhadap pramuwisata lokal untuk menunjang kualitas SDM pada daya tarik wisata Alas Kedaton.
\end{abstract}

Kata Kunci : Kualitas Pelayanan, Kepuasan, Loyalitas, Pramuwisata Lokal.

\section{PENDAHULUAN}

Bali merupakan pulau yang memiliki potensi pariwisata yang besar. Bali dikembangkan sebagai destinasi pariwisata berbasis pada budaya serta didukung oleh keindahan alam yang sangat indah dan menarik. Pulau Bali telah mengalami kemajuan yang sangat pesat. Jumlah wisatawan yang datang ke Bali dalam lima tahun terakhir dari tahun 2008 sampai tahun 2014 terus mengalami peningkatan dengan rata - rata peningkatan sebesar 9, 82\%. Pengembangan sektor pariwisata dengan baik akan mampu menarik wisatawan domestik maupun wisatawan asing untuk datang dan berwisata. Pengembangan pariwisata harus merupakan pengembangan yang terencana secara menyeluruh sehingga bisa memberi manfaat bagi masyarakat, baik dari segi ekonomi, sosial, dan kultural.

Alas Kedaton merupakan sebuah daya tarik wisata yang terdapat di Kabupaten 
Tabanan, Bali. Berupa kawasan suci hutan lindung dengan luas 12,5 hektar yang ditumbuhi berbagai macam dan jenis tumbuhan, dan dihuni ribuan monyet, ratusan kelelawar, dan binatang lainnya. Alas Kedaton terletak di desa Kukuh Kecamatan Marga yang berjarak sekitar $4 \mathrm{~km}$ dari kota Tabanan.

Salah satu penunjang yang ada di daya tarik wisata Alas Kedaton adalah pramuwisata lokal. Pramuwisata menurut Mancini (2001), adalah orang yang membawa orang-orang (wisatawan) untuk melakukan kegiatan kunjungan menurut jangka waktu tertentu Di Alas Kedaton, pramuwisata lokal adalah pedagang yang ada di alas kedaton maupun pramuwisata lokal khusus yang menunggu kedatangan wisatawan di luar daya tarik wisata Alas Kedaton. Setiap pengunjung yang datang ke Alas Kedaton wajib ditemani oleh pramuwisata Lokal disana.

Pramuwisata adalah orang yang berhadapan langsung dengan wisatawan, sehingga kualitas pelayanan dari pramuwisata lokal akan mempengaruhi kepuasan wisatawan. Kualitas pelayanan sendiri menurut philip kotler (2006) terdiri dari lima dimensi, yaitu bukti langsung, empati, keandalan, jaminan dan daya tanggap. Jika pengelola Alas Kedaton ingin membuat wisatawan yang berkunjung menjadi puas, maka tingkat pelayanan yang diberikan harus melebihi harapan dari wisatawan. Manfaat dari kualitas pelayanan yang baik dari pramuwisata lokal tersebut antara lain meningkatkan kepuasan. Definisi kepuasan wisatawan menurut Kotler dan Keller (2009) adalah perasaan senang atau kecewa seseorang yang timbul karena membandingkan kinerja yang dipresepsikan produk (atau hasil) terhadap ekspektasi mereka.

Selain kepuasan, kualitas pelayanan juga akan berpengaruh terhadap citra dan loyalitas para wisatawan. Adapun pengertian Loyalitas menurut Sutisna (2001) merupakan sikap menyenangi terhadap suatu merek atau jasa yang direpresentasikan dalam pembelian yang konsisten terhadap merek atau jasa itu sepanjang waktu. Dengan pelayanan yang baik serta potensi dari Alas Kedaton tentu akan meningkatkan citra dari Alas Kedaton di mata wisatawan sehingga wisatawan merasa nyaman untuk datang berkunjung lagi.

Menurut I Gusti Bagus Suryawan selaku manejer pengelola Daya Tarik Wisata Alas Kedaton saat diwawancarai tanggal 25 November 2014, Sempat menjadi ikon pariwisata di Tabanan karena tingginya jumlah kunjungan wisatawan pada tahun sembilan puluhan, namun kini minat wisatawan untuk datang ke Alas Kedaton berkurang. Menurut I Gusti Bagus Suryawan selaku manejer pengelola daya tarik wisata Alas Kedaton, Alas Kedaton tidak mampu berkembang dengan baik dan mengakibatkan wisatawan lebih memilih tempat lain yang memiliki potensi sama tapi menawarkan produk yang lebih menarik.

Masih banyak kekurangan yang harus diperbaiki guna menjadikan Alas Kedaton kembali menjadi daya tarik wisata yang diminati bagi wisatawan. Sampai saat ini belum dapat diketahui apakah kualitas pelayanan pramuwisata lokal berpengaruh pada kepuasan wisatawan dan loyalitas wisatawan pada daya tarik wisata Alas Kedaton. Sehingga menarik untuk dicermati apakah kualitas pelayanan pramuwisata lokal yang ada di Alas Kedaton, berpengaruh terhadap tingkat kepuasan wisatawan dan juga loyalitas wisatawan ke Daya Tarik Wisata Alas Kedaton. Untuk melengkapi kajian ini, juga akan dibahas juga mengenai persepsi wisatawan terhadap lima indikator pelayanan pramuwisata lokal serta indikator kepuasan dan loyalitas.

\section{METODE}

Lokasi yang menjadi fokus penyebaran kuesioner yaitu pada Daya Tarik Wisata Alas Kedaton Tabanan. Selanjutnya Pengumpulan data dilakukan dengan cara observasi, wawancara terstruktur, kuesioner, dan studi kepustakaan. Kuesioner disebar kepada 100 responden wisatawan yang berkunjung ke daya tarik wisata alas kedaton dengan menggunakan teknik penentuan sampel accidental sampling. Kemudian data dari kuesioner akan dijabarkan menggunakan analisis skala likert( kusmayadi dan endar, 2000 ) dengan lima poin penilaian. Teknik 
analisis yang digunakan adalah teknik analisis uji validitas dan realibilitas (Gozhali, 2005) Analisis Regresi Linier Berganda (Wirawan 2000), dengan persamaan $\mathbf{Y}=$ $a+b 1 X 1+b 2 X 2+b 3 X 3+b 1 X 4$

(ni), dimana koefisien Regresi tersebut kemudian diuji secara parsial menggunakan uji t-test dan secara simultan dengan menggunakan F-test. Analisis Korelasi (Buchari, 2006) dan Analisis Determinasi (Sudjana, 1993).

\section{HASIL}

Hasil persepsi wisatawan terhadap lima variabel kualitas pelayanan pramuwisata lokal, kepuasan dan loyalitas wisatawan pada daya tarik wisata Alas Kedaton, dapat dilihat dalam tabel berikut:

Tabel 1.

Persepsi wisatawan Terhadap Indikator Pelayanan Pramuwisata lokal, Kepuasan dan Loyalitas Wisatawan

\begin{tabular}{|c|c|c|c|}
\hline No & Variabel & $\begin{array}{l}\text { Indikator } \\
\text { Tertinggi }\end{array}$ & Skor \\
\hline 1 & $\begin{array}{l}\text { Bukti } \\
\text { Langsung } \\
\text { (X1) }\end{array}$ & $\begin{array}{l}\text { Pakaian yang } \\
\text { digunakan } \\
\text { pramuwisata } \\
\text { lokal di daya } \\
\text { tarik wisata } \\
\text { Alas Kedaton } \\
\text { sudah rapi, } \\
\text { bersih dan } \\
\text { mencerminkan } \\
\text { adat orang Bali }\end{array}$ & $\begin{array}{c}3,34 \\
\text { (Setuju) }\end{array}$ \\
\hline 2 & $\begin{array}{l}\text { Empati } \\
\text { (X2) }\end{array}$ & $\begin{array}{l}\text { Pramuwisata } \\
\text { lokal di daya } \\
\text { tarik wisata } \\
\text { Alas Kedaton } \\
\text { telah } \\
\text { memberikan } \\
\text { perhatian yang } \\
\text { baik terhadap } \\
\text { kebutuhan yang } \\
\text { diperlukan oleh } \\
\text { wisatawan }\end{array}$ & $\begin{array}{c}3,43 \\
\text { (Setuju) }\end{array}$ \\
\hline 3 & $\begin{array}{l}\text { Daya } \\
\text { Tanggap } \\
\text { (X3) }\end{array}$ & $\begin{array}{l}\text { Pramuwisata } \\
\text { lokal di daya } \\
\text { tarik wisata } \\
\text { Alas Kedaton } \\
\text { senantiasa } \\
\text { membantu }\end{array}$ & $\begin{array}{c}3,50 \\
\text { (Setuju) }\end{array}$ \\
\hline
\end{tabular}

\begin{tabular}{|c|c|c|c|}
\hline & & $\begin{array}{l}\text { wisatawan } \\
\text { ketika } \\
\text { membutuhkan } \\
\text { bantuan }\end{array}$ & \\
\hline 4 & $\begin{array}{l}\text { Keandalan } \\
\text { (X4) }\end{array}$ & $\begin{array}{l}\text { Pramuwisata } \\
\text { lokal di daya } \\
\text { tarik wisata } \\
\text { Alas Kedaton } \\
\text { telah } \\
\text { memanfaatkan } \\
\text { waktu dengan } \\
\text { efisien }\end{array}$ & $\begin{array}{c}3,61 \\
\text { (Setuju) }\end{array}$ \\
\hline 5 & $\begin{array}{l}\text { Jaminan } \\
\text { (X5) }\end{array}$ & 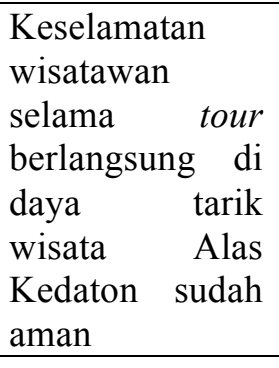 & $\begin{array}{l}3,46 \\
\text { (Setuju) }\end{array}$ \\
\hline 6 & $\begin{array}{l}\text { Kepuasan } \\
\text { (Y1) }\end{array}$ & $\begin{array}{l}\text { Dengan adanya } \\
\text { pramuwisata } \\
\text { lokal wisatawan } \\
\text { merasa } \\
\text { terbantukan } \\
\text { baik dari segi } \\
\text { keselamatan dan } \\
\text { penjelasan } \\
\text { selama } \\
\text { berkunjung di } \\
\text { daya tarik } \\
\text { wisata Alas } \\
\text { Kedaton }\end{array}$ & $\begin{array}{c}3,60 \\
\text { (Setuju) }\end{array}$ \\
\hline 7 & $\begin{array}{l}\text { Loyalitas } \\
\text { (Y2) }\end{array}$ & $\begin{array}{l}\text { Setiap datang ke } \\
\text { Bali wisatawan } \\
\text { ingin } \\
\text { mengunjungi } \\
\text { daya tarik } \\
\text { wisata Alas } \\
\text { Kedaton }\end{array}$ & $\begin{array}{c}3,63 \\
\text { (Setuju) }\end{array}$ \\
\hline
\end{tabular}

Sumber : Hasil analisis data 2015

Dari tabel 1, pada variabel independen yaitu kualitas pelayanan (X), penilaian tertinggi wisatawan terhadap indikator adalah pada variabel Keandalan $\left(\mathrm{X}_{4}\right)$ dengan indikator yaitu pramuwisata lokal di daya tarik wisata Alas Kedaton telah memanfaatkan waktu dengan efisien mungkin saat memberikan penjelasan selama 
tour berlangsung. Sedangkan dalam variabel dependen, yaitu kepuasan $\left(\mathrm{Y}_{1}\right)$ dan Loyalitas $\left(\mathrm{Y}_{2}\right)$ dapat diketahui, penilaian tertinggi wisatawan terhadap indikator yang ada pada variabel Loyalitas wisatawan yaitu indikator Setiap datang ke Bali wisatawan ingin mengunjungi daya tarik wisata Alas Kedaton.

Pada hasil analisis pengujian Validitas dan Realibilitas, dapat diketahui dari 23 indikator dimana 17 indikator dalam variabel Kualitas Pelayanan (X), 3 indikator Kepuasan Wisatawan $\left(\mathrm{Y}_{1}\right)$ dan 3 indikator dalam Loyalitas WIsatawan $\left(\mathrm{Y}_{2}\right)$ dinyatakan valid dan realibel karena koefisien korelasi dan conbach alpha telah memenuhi syarat pengujian, dimana melebihi 0,3 untuk pengujian validitas dan 0,6 untuk pengujian realibilitas.

Dari hasil analisis regresi linier berganda, dari persamaan kualitas pelayanan terhadap kepuasan wisatawan dapat dilihat dari tabel berikut :

Tabel 2

Analisis Regresi Linier Berganda Terhadap Kepuasan Wisatawan Coefficients

\begin{tabular}{|c|c|c|c|c|c|c|}
\hline & & \multicolumn{2}{|c|}{$\begin{array}{l}\text { Unstandardized } \\
\text { Coefficients }\end{array}$} & \multirow{2}{*}{$\begin{array}{c}\text { Standardized } \\
\text { coefficients } \\
\text { Beta }\end{array}$} & \multirow[b]{2}{*}{$t$} & \multirow[b]{2}{*}{ Sig. } \\
\hline & Model & & Std. Eror & & & \\
\hline 1 & (Constant) & 1,819 & 831 & & 2,188 &, 031 \\
\hline & Bukti langsung & 105 & .041 & .140 & 2,590 & 011 \\
\hline & Enpati &, 211 & ,037 &, 298 & 5,737 & , 000 \\
\hline & Daya tanggap & 258 & .034 & 392 & 7,634 & 000 \\
\hline & Keandalan & 242 & 040 & 317 & 6,113 & 000 \\
\hline & Jaminan & 318 & 037 & .473 & 8,647 & 000 \\
\hline
\end{tabular}

sumber : Hasil analisis data 2015

Berdasarkan pada tabel, didapat persamaan regresi variabel kepuasan wisatawan sebesar : $\mathrm{Y}_{1}=1,819+0,105 \mathrm{X}_{1}+$ $0,211 X_{2}+0,258 X_{3}+0,242 X_{4}+0,318 X_{5}$ selanjutnya persamaan linier berganda dari persamaan regresi variabel kualitas pelayanan terhadap loyalitas wisatawan dapat dilihat dari tabel berikut:

\section{Tabel 3}

Analisis Regresi Linier Berganda Terhadap Loyalitas Wisatawan

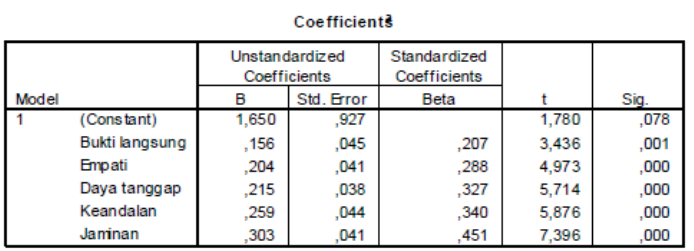

Sumber : Hasil analisis data 2015

Dari tabel 3 diatas, maka didapat
persamaan wisatawan sebesar : $\mathrm{Y}_{2}=1,650+0,156 \mathrm{X}_{1}+$ $0,204 X_{2}+0,215 X_{3}+0,259 X_{4}+0,303 X_{5}$.

Pada hasil analisis regresi berganda yang telah dilakukan,secara parsial lima variabel independen telah terbukti berpengaruh positif dan signifikan terhadap variabel dependen, karena telah memenuhi syarat penerimaan hipotesis, yaitu t-hitung lebih besar dibandingkan $\mathrm{t}_{\text {tabel }}$ sehingga hipotesis dalam penelitian ini telah terbukti. Hasil tersebut bisa dilihat dalam gambar berikut

\section{Gambar 1}

\section{Kurva Penentuan Penerimaan dan}

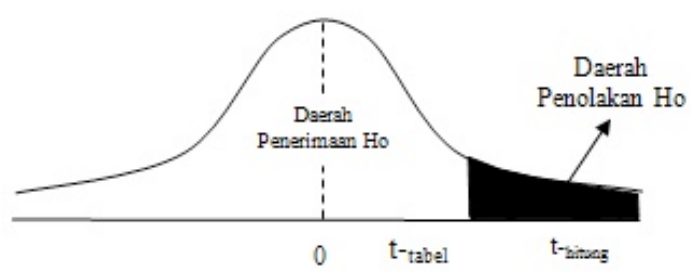

Penolakan Hipotesis Secara Parsial

Sumber : Hasil analisis data 2015

Dari hasil uji signifikan secara simultan (uji F) diketahui $\mathrm{F}$ hitung lebih besar dari $F$ tabel sehingga terdapat hubungan yang signifikan antara kualitas pelayanan pramuwisata lokal terhadap kepuasan dan loyalitas wisatawan. Hal itu bisa dilihat dari gambar berikut :

\section{Gambar 2}

\section{Kurva Penentuan Penerimaan dan}

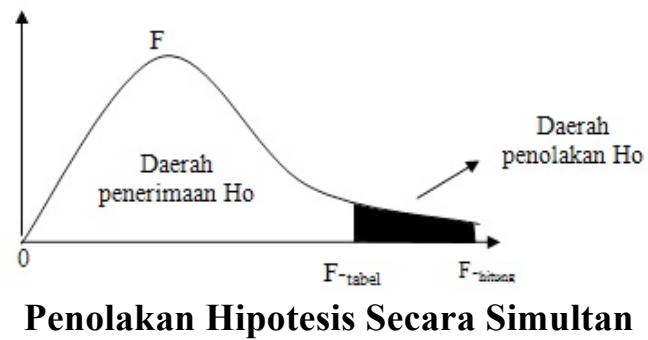

Sumber Hasil analisis data 2015

Dari hasil analisis korelasi, Berikut merupakan hasil nilai korelasi antara kualitas pelayanan $(\mathrm{X})$ terhadap kepuasan wisatawan $\left(\mathrm{Y}_{1}\right)$ adalah : 
Tabel 4

Analisis korelasi terhadap kepuasan wisatawan

\begin{tabular}{|l|l|l|}
\hline No & Model & Korelasi \\
\hline 1 & $\begin{array}{l}\text { Kualits pelayanan - } \\
\text { kepuasan wisatawan }\end{array}$ & 0,874 \\
\hline
\end{tabular}

Sumber : Hasil analisis data 2015

Dan hasil nilai korelasi antara kualitas pelayanan (X) terhadap loyalitas wisatawan $\left(\mathrm{Y}_{2}\right)$ adalah :

\section{Tabel 5}

Analisis Korelasi Terhadap Loyalitas Wisatawan

\begin{tabular}{|l|l|l|}
\hline No & Model & Korelasi \\
\hline 1 & $\begin{array}{l}\text { Kualits pelayanan - } \\
\text { loyalitas wisatawan }\end{array}$ & 0,840 \\
\hline
\end{tabular}

Sumber : Hasil analisis data 2015

Dengan nilai Korelasi sebesar 0, 874 pada tabel 4 dan 0,840 pada tabel 5 , dapat diartikan bahwa ada pengaruh yang Sangat Kuat antara kualitas pelayanan pramuwisata lokal terhadap kepuasan dan loyalitas wisatawan yang berkunjung ke daya tarik wisata Alas Kedaton Tabanan.

Berdasarkan hasil analisis determinasi, didapatkan nilai perhitungan determinasi Untuk kepuasan wisatawan yang nilai korelasinya $\mathrm{R}=0,874$ maka diperoleh perhitungan nilai determinasi sebagai berikut

$\mathrm{D}=(0,874)^{2} \times 100 \%$

$\mathrm{D}=0,764 \times 100 \%$

$\mathrm{D}=76,4 \%$

Selanjutnya nilai determinasi untuk loyalitas wisatawan yang nilai korelasinya $R=0,840$ maka diperolehh perhitungan determinasi sebagai berikut :

$\mathrm{D}=(0,840)^{2} \times 100 \%$

$\mathrm{D}=0,706 \times 100 \%$

$\mathrm{D}=70,6 \%$

Melalui hasil tersebut dapat diartikan bahwa kualitas pelayanan pramuwisata lokal berpengaruh sebesar $76,4 \%$ terhadap kepuasan wisatawan, dan $70,6 \%$ terhadap loyalitas wisatawan.

\section{PEMBAHASAN}

Untuk membahas hasil yang sudah dianalisis dengan metode kuantitatif, maka selanjutnya dibahas dengan mendeskripsikan hasil yang telah didapat.

Dari hasil 100 sampel terhadap wisatawan yang berkunjung ke Daya Tarik Wisata Alas Kedaton, wisatawaan yang datang didominasi oleh wisatawan dengan jenis kelamin laki - laki , dengan umur dibawah 20 tahun yang mayoritas pelajar domestik yang berasal dari Indonesia tapi diluar Bali dengan Frekuensi berkunjung lebih dominan baru pertama kali berkunjung ke Alas Kedaton.

Pada hasil Persepsi Terhadap Indikator Pelayanan Pramuwisata lokal, Kepuasan dan Loyalitas Wisatawan dapat diketahui pada variabel independen yaitu kualitas pelayanan $(\mathrm{X})$, penilaian tertinggi wisatawan terhadap indikator yaitu pramuwisata lokal di daya tarik wisata Alas Kedaton telah memanfaatkan waktu dengan efisien mungkin saat memberikan penjelasan selama tour berlangsung. Dan penilian terkcil adalah indikator Pramuwisata lokal di daya tarik wisata Alas Kedaton sudah memberikan informasi dengan baik dan jelas sesuai dengan program paket tour yang mereka jalankan. Sedangkan dalam variabel dependen, yaitu kepuasan $\left(\mathrm{Y}_{1}\right)$ dan Loyalitas $\left(\mathrm{Y}_{2}\right)$ dapat diketahui, penilaian tertinggi wisatawan terhadap indikator yang ada pada variabel Loyalitas wisatawan yaitu indikator Setiap datang ke Bali wisatawan ingin mengunjungi daya tarik wisata Alas Kedaton.

Pada hasil analisis regresi berganda yang telah dilakukan,secara parsial lima variabel independen telah terbukti berpengaruh positif dan signifikan terhadap variabel dependen, karena telah memenuhi syarat penerimaan hipotesis, yaitu $t_{\text {-hitung }}$ lebih besar dibandingkan $\mathrm{t}_{\text {-tabel }}$ sehingga hipotesis dalam penelitian ini telah terbukti. Hal tersebut bisa dilihat dari Dari hasil uji signifikan secara parsial (uji t) Penentuan uji $\mathrm{t}$, yaitu:

Ho : $b_{1} \leq 0$, Variabel bebas yang meliputi bukti langsung $\left(\mathrm{X}_{1}\right)$, empati $\left(\mathrm{X}_{2}\right)$, daya tanggap $\left(\mathrm{X}_{3}\right)$, keandalan $\left(\mathrm{X}_{4}\right)$, dan jaminan $\left(\mathrm{X}_{5}\right)$, secara parsial tidak berpengaruh positif terhadap variabel terikat kepuasan dan loyalitas wisatawan 
$\mathrm{H}_{1}: \mathrm{b}_{1}>0$, Variabel bebas yang meliputi bukti langsung $\left(\mathrm{X}_{1}\right)$, empati $\left(\mathrm{X}_{2}\right)$, daya tanggap $\left(\mathrm{X}_{3}\right)$, keandalan $\left(\mathrm{X}_{4}\right)$, dan jaminan $\left(\mathrm{X}_{5}\right)$, secara parsial berpengaruh positif terhadap variabel terikat kepuasan loyalitas wisatawan

Dan penentuan hipotesis adalah

1. Jika $\mathrm{t}_{\text {-hitung }} \leq \mathrm{t}_{\text {-tabel }}$ dan nilai sig. $>$ alpha $5 \%(0,05)$ maka $_{0}$ diterima

2. Jika t-hitung $>\mathrm{t}_{\text {-tabel }}$ dan nilai sig. $<$ alpha $5 \%(0,05)$ maka $\mathrm{H}_{0}$ ditolak

Dari variabel kualitas pelayanan terhadap kepuasan wisatawan nilai $t_{\text {-hitung bukti }}$ langsung $\left(\mathrm{X}_{1}\right)$, empati $\left(\mathrm{X}_{2}\right)$, daya tanggap $\left(\mathrm{X}_{3}\right)$, keandalan $\left(\mathrm{X}_{4}\right)$, dan jaminan $\left(\mathrm{X}_{5}\right)$ adalah : $X_{1}=2,590, X_{2}=5,737, X_{3}=7,634$, $\mathrm{X}_{4}=6,113, \mathrm{X}_{5}=8,647$ dan $\mathrm{t}$-tabel sebesar 1,660. Dan nilai t-hitung dari variabel kualitas pelayanan terhadap loyalitas wisatawan adalah : $X_{1}=3,436, X_{2}=4,973$, $\mathrm{X}_{3}=5,714, \mathrm{X}_{4}=5,876, \mathrm{X}_{5}=7,396$ dan $\mathrm{t}_{\text {tabe }} \mathrm{l}$ sebesar 1,660.

Dapat dilihat bahwa $t_{\text {-hitung }}$ dari semua variabel lebih besar dari $t_{\text {tabel }}(1,660)$, maka $\mathrm{H}_{0}$ ditolak dan $\mathrm{H}_{1}$ diterima yang berarti terdapat pengaruh positif dan signifikan antar variabel $\mathrm{X}_{1}, \mathrm{X}_{2}, \mathrm{X}_{3}, \mathrm{X}_{4}, \mathrm{X}_{5}$ terhadap kepuasan dan loyalitas wisatawan

Penerimaan dan penolakan $\mathrm{H}_{0}$ dapat dilihat dalam gambar berikut :

Dari hasil uji signifikan secara simultan (uji F) dapat diketahui besarnya nilai $\mathrm{F}_{\text {-hitung }}$ dari variabel kualitas pelayanan terhadap kepuasan wisatawan adalah 60,770 dan $\mathrm{F}_{\text {-tabel }}$ sebesar 2,32. Sedangkan nilai dari $\mathrm{F}_{\text {-hitung }}$ variabel kualitas pelayanan terhadap loyalitas wisatawan adalah sebesar 45,129 dan $\mathrm{F}_{\text {-tabel }}$ sebesar 2,32.

Dengan kriteria penerimaan / penolakan hipotesis pengaruh simultan variabel bebas terhadap variabel terikat adalah:

a). Jika $F_{\text {hitung }} \leq \mathrm{F}_{\text {tabel }}$ dan nilai sig.> alpha $5 \%$ $(0,05)$ maka $\mathrm{H}_{0}$ diterima

b). Jika $\mathrm{F}_{\text {hitung }}>\mathrm{F}_{\text {tabel }}$ dan nilai sig. $<$ alpha $5 \%$ $(0,05)$ maka $\mathrm{H}_{0}$ ditolak

Diketahui nilai $\mathrm{F}_{\text {-hitung }}$ lebih besar dari $\mathrm{F}_{\text {-tabel }}$ maka $\mathrm{H}_{0}$ ditolak dadan $\mathrm{H}_{1}$ diterima, maka variabel bebas yaitu kualitas pelayanan secara simultan berpengaruh signifikan terhadap variabel Kepuasan dan loyalitas
Wisatawan ke Daya Tarik Wisata Alas Kedaton.

Dari lima variabel independen tersebut, variabel yang lebih berpengaruh pada variabel dependen baik itu variabel kepuasan wisatawan $\left(\mathrm{Y}_{1}\right)$ maupun variabel loyalitas wisatawan $\left(\mathrm{Y}_{2}\right)$ adalah variabel Jaminan $\left(\mathrm{X}_{5}\right)$ karena variabel Jaminan

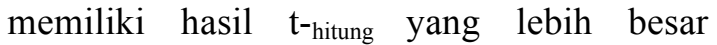
dibandingkan hasil t-hitung pada variabel independen lainnya. Secara simultan, lima variabel independen terbukti berpengaruh terhadap variabel dependen, karena $\mathrm{F}_{\text {-hitung }}$ lebih besar dibandingkan $\mathrm{F}_{\text {-tabel }}$ sehingga telah memenuhi syarat penerimaan hipotesis.

Dari hasil analisis korelasi, untuk mengetahui kekuatan hubungan antara kualitas pelayanan terhadap kepuasan dan loyalitas wisatawan, dapat diartikan bahwa ada hubungan atau pengaruh yang kuat antara indikator independen yaitu kualitas pelayanan pramuwisata lokal terhadap indikator dependen yaitu kepuasan dan loyalitas wisatawan yang berkunjung ke daya tarik wisata Alas Kedaton Tabanan karena hasil yang didapat telah memenuhi kuat derajat hubungan koefisien korelasi dimana hubungannya adalah sangat kuat. Pada hasil analisis determinasi dimana untuk mengetahui sejauh mana pengaruh variabel independen terhadap variabel dependen, diketahui jika pengaruh variabel kualitas pelayanan pramuwisata lokal terhadap varibel Kepuasan Pelayanan adalah sebesar $76,4 \%$, sedangkan terhadap variabel Loyalitas Wisatawanadalah 70,6 \%. Ini menunjukan bahwa variabel Kualitas Pelayanan pramuwisata lokal cukup signifikan mempengaruhi kepuasan dan loyalitas wisatawan yang berkunjung ke Daya Tarik Wisata Alas Kedaton.

\section{SIMPULAN}

Berdasarkan pembahasan, maka dapat diperoleh hasil bahwa terdapat hubungan yang signifikan antara kualitas pelayanan pramuwisata lokal terhadap kepuasan dan loyalitas wisatawan di daya tarik wisata Alas Kedaton. Hal ini dapat dilihat dari perhitungan analisis regresi berganda, Dari hasil analisis korelasi kualitas pelayanan terhadap Kepuasan dan loyalitas 
wisatawan, serta dari hasil analisis determinasi, dapat diartikan bahwa ada hubungan atau pengaruh yang sangat kuat antara kualitas pelayanan pramuwisata lokal terhadap kepuasan wisatawan yang berkunjung ke daya tarik wisata Alas Kedaton Tabanan. Semakin berkualitas pelayanan yang diberikan pramuwisata lokal maka kepuasan wisatawan akan semakin meningkat, begitu pula sebaliknya

\section{SARAN}

Berdasarkan hasil pembahasan yang telah dibuat, maka dapat diberikan saran yang dianggap perlu yakni, Kualitas pelayanan yang diberikan oleh pramuwisata lokal pada daya tarik wisata Alas Kedaton terhadap wisatawan untuk menunjang kepuasan dan loyalitas wisatawan maka diperlukan adanya perbaikan terhadap berperilaku sopan disaat berkomunikasi dengan wisatawan, memberikan informasi dengan baik dan jelas sesuai dengan program paket tour yang mereka jalankan, dan memberikan jaminan asuransi keselamatan dan keamanan kepada wisatawan dan tidak lupa perlengkapan kesehatan (P3K) yang disiapkan. agar kepuasan wisatawan lebih meningkat dari yang sudah ada. Perlu dilakukan penelitian lebih lanjut untuk meningkatkan lagi kekurangan yang terdapat di daya tarik wisata Alas Kedaton sehingga kembali diminati oleh wisatawan.

\section{DAFTAR PUSTAKA}

Buchari, Alma. 2006. Pemasaran dan Pemasaran Jasa. Bandung: Alfabeta

Ghozali, Imam. 2005. Aplikasi Analisis Multivariate dengan Program SPSS. Semarang : Badan Penerbit Universitas Diponogoro

Kotler, philip and Gary Amstrong. 2006. Prinsip-prinsip Pemasaran jilid $1 \& 2$. Jakarta : Erlangga.

Kotler, Philip and Kevin Lane Keller. 2009. Manajemen Pemasaran jilid 1. Edisi sembilan. Jakarta : Erlangga

Kusmayadi, Endar. 2000. Metode Penelitian dalam Bidang Kepariwisataan. Jakarta: PT Gramedia Pusataka Utama
Mancini. 2001. Conducting Tours. Third edition. USA : Delmar

Sudjana, 1993. Metode Statitiska. Bandung : Tarsito

Sutisna. 2001. Perilaku Konsumen dan Komunikasi Pemasaran. Bandung : Remaja Rosdakarya.

Wirawan. 2002. Profesi dan Standar Evaluasi. Jakarta: Yayasan \& Umhamka Press. 